\title{
Health Related Campaigns in Social Media and Its Practical Aspects for Youths in Malaysia
}

\author{
Suffian Hadi Ayub ${ }^{1 *}$, Yesuselvi Manickam ${ }^{1}$, Mohammed Rezal Hamzah ${ }^{2}$, Julinawati \\ Suanda $^{3}$ and Husna Afifi Mohd Yusoff ${ }^{2}$ \\ ${ }^{1}$ DCLA, School of Arts, Sunway University, 46150 Petaling Jaya, Selangor, Malaysia \\ ${ }^{2}$ IKOM, Universiti Malaysia Perlis, 01000 Kangar, Perlis, Malaysia \\ ${ }^{3}$ PPIPT, Universiti Malaysia Perlis, 01000 Kangar, Perlis, Malaysia
}

\begin{abstract}
The paper discusses the importance of social media in today's society and review how health related campaign could penetrate the youths in Malaysia. In the internet age, the youths are divided into two; the digital natives (born after 1980) and digital immigrants (born before 1980). Further to that, the paper provides an insight on how past efforts by relevant stakeholders were utilised in creating awareness to Malaysian youths through the social media. Upon identifying the efforts through extensive literature review, the usage of social media in propagating behavioural changes in youths' were also discussed. Several meaningful impacts were discovered and must be carefully considered in terms of its practical implications to suit Malaysian youths.
\end{abstract}

\section{Introduction}

In the technological era, the Internet has been touted as the most effective way to reach the people. Its reachability and coverage surpasses other media; either traditional or electronic. Any service sector has now utilised the Internet to send messages and promote its product to users. The government and non-government alike too are moving towards strengthening its presence in the Internet. The advent of social media introduce flexibility to its users in managing information. The social media too have opened up more room for the industry to flex its muscle in engaging the publics and this include health industry. Although the government and private sector play an important role in communicating with the publics on health issues, the role that Non-government organisations (NGOs) carry too are equally important. It is the NGOs that are more close to the stakeholders and these groups too are responsible to strengthen whatever effort that the government is working on.

The health related campaign via the social media often targeting youths in particular, because this group spend more time online. This further illustrates the importance of the Internet to the authorities in reaching out to its intended/targeted public. Undoubtedly, NGOs have always been the backbone to both the government and the people. Its very existence elucidates the importance of the cause that it champion. In the health industry,

\footnotetext{
*Corresponding author: suffianay@,sunway.edu.my
} 
NGOs play a pivotal role in educating the public about current situation and early prevention. These activities, in return assist the government in reducing the treatment costs and other associated financial issues which has alarmingly becoming higher than before. In today's society where youths are the important investment for the country, lack of education and awareness on diseases and its prevention has put them at risk and even more so making it highly challenging to combat due to the rising cost of medication and treatment.

\section{Methodology}

The paper employed content analysis to probe further into the usage of social media among organisations and public figures pertaining to health related campaign aiming at youths in Malaysia. The primary goal of the content analysis was to investigate the role of social media usage in the internet and the types of information provided by the organisations and public figures with regards to health related campaign and its outreach to youths specifically and public in general.

The fact that youths largely contributed to the development of the nation signal the call for the government to play greater emphasis on youths' health issues and government alone could not achieve this. Subsequently, NGOs are expected to champion the health related campaign to create awareness among youths. The measurement of health related campaign and its effectiveness will ensure a comprehensive and sustained effort by the NGOs. This is vital as it deduce a meaningful impact in educating youths which later will create a holistic health conscious society which is detrimental to nation's building.

Youth constitutes half of the Malaysian population [4]. Statistics from Department of Statistical Malaysia shows that in 2008, from 27.7 million people in Malaysia, 11.26 million people $(40.6 \%)$ is from youth group. Meanwhile, it is expected that in 2012, the number of youth in Malaysia will be increased to 11.65 million (40.2\%). Youth represent a significant group in a society. Youth characteristics within society are able to either give hope or despair to the country. In the current era, most of the issues and social problems happened in Malaysia involved the youth [5]. As such, the notion to create a health conscious society in Malaysia must include youths. In producing a public health campaign aims at youths, the NGOs must be able to categorically define what appeal the most to this demographic group.

Generation Y actively contributes, shares, searches for and consumes content - plus works and plays - on social media platforms [8]. They are the first generation to have spent their entire lives in the digital environment; information technology profoundly affects how they live and work $[2,10]$. Further to this, marketing categorised health campaign as one of social marketing where marketing plays a vital role in market penetration strategies. Marketing in its wider definition is suitable to be applied in assessing the social media usage through the differences of market segment such as the immigrants and natives digital users [10]. This provides a cautionary reminder that the insertion of public health campaign must be carefully constructed to ensure maximum exposure and behavioural changes. As a matter of fact, social norms and behaviour may be changing due to Generation Y's use of social media - affecting civic engagement, attitude towards privacy, nutrition, health care practices and public safety in the general population [8]. 


\section{Findings}

The results of the content analysis on the usage of social media among organisations and individuals (governments, NGOs, public figures) have indicated that the trend is increasingly positive with a steady growth in the numbers of followers / subscribers / likes. The content analysis was conducted on various organisations and individuals across the spectrum of social media platform such as Facebook, Instagram, Twitter and Youtube. Result of the content analysis are provided in Table I.

Table 1. The usage of social media among organisations in Malaysia

\begin{tabular}{|c|c|c|c|c|c|}
\hline $\begin{array}{l}\text { Institute } \\
\quad / \\
\text { Organis } \\
\text { ation }\end{array}$ & $\begin{array}{c}\text { No. of } \\
\text { like / } \\
\text { subscrib } \\
\text { ers }\end{array}$ & Urls / link & Focus & Status & $\begin{array}{l}\text { Type of } \\
\text { social } \\
\text { media }\end{array}$ \\
\hline $\begin{array}{l}\text { Ministry } \\
\text { of } \\
\text { Health } \\
(\mathrm{MoH})\end{array}$ & 628,194 & $\begin{array}{l}\text { https://www.face } \\
\text { book.com/kement } \\
\text { erankesihatanmal } \\
\text { aysia/?fref=nf }\end{array}$ & $\begin{array}{l}\text { Health campaign, } \\
\text { diseases, origin of } \\
\text { sickness, treatment, } \\
\text { symptoms }\end{array}$ & Government & Facebook \\
\hline $\mathrm{MoH}$ & $37.7 \mathrm{k}$ & $\begin{array}{l}\text { Various health } \\
\text { related } \\
\text { information }\end{array}$ & $\begin{array}{l}\text { Health campaign, } \\
\text { diseases, origin of } \\
\text { sickness, treatment, } \\
\text { symptoms }\end{array}$ & Government & Instagram \\
\hline Mercy & 56,201 & $\begin{array}{l}\frac{\underline{\text { https://www.face }}}{\text { book.com/MERC }} \\
\underline{\text { Ymalaysia/?fref }=} \\
\underline{\text { ts }}\end{array}$ & Health campaign & NGO & Facebook \\
\hline Makna & 39,324 & $\begin{array}{l}\underline{\text { https://www.face }} \\
\text { book.com/makna } \\
\text { cancer/?fref=ts }\end{array}$ & Health campaign & NGO & Facebook \\
\hline $\begin{array}{l}\text { Dr. Sahit } \\
\text { Arshat }\end{array}$ & 236,311 & $\frac{\underline{\text { https://www.face }}}{\underline{\text { book.com/hamida }}} \underline{\underline{\text { rshat } 45 / ? \text { fref }=\text { ts }}}$ & $\begin{array}{l}\text { Diseases, origin of } \\
\text { sickness, treatment, } \\
\text { symptoms, health } \\
\text { campaign }\end{array}$ & $\begin{array}{c}\text { Individual / } \\
\text { physician }\end{array}$ & Facebook \\
\hline $\begin{array}{l}\text { Prof. Dr. } \\
\text { Muhaya }\end{array}$ & 103,9812 & $\begin{array}{l}\underline{\mathrm{https}: / / \mathrm{www} \cdot \text { face }} \\
\underline{\text { book.com/profdr }} \\
\underline{\text { muhaya/?fref=ts }}\end{array}$ & $\begin{array}{l}\text { Diseases, origin of } \\
\text { sickness, treatment, } \\
\text { symptoms, health } \\
\text { campaign }\end{array}$ & $\begin{array}{l}\text { Individual / } \\
\text { physician }\end{array}$ & Facebook \\
\hline $\begin{array}{l}\text { Mmgaze } \\
\text { tte }\end{array}$ & 4,639 & @MMGazette & $\begin{array}{l}\text { Diseases, origin of } \\
\text { sickness, treatment, } \\
\text { symptoms, health } \\
\text { campaign }\end{array}$ & NGO & Twitter \\
\hline $\begin{array}{l}\text { MedTwe } \\
\text { etMy }\end{array}$ & 6,556 & $\begin{array}{l}@ \text { @MedTweetMY } \\
\text { HQ }\end{array}$ & Health campaign & NGO & Twitter \\
\hline $\begin{array}{l}\text { Myhealt } \\
\text { hkkm }\end{array}$ & $\begin{array}{c}360 \\
\text { videos }\end{array}$ & $\begin{array}{l}\underline{\text { https://www.yout }} \\
\text { ube.com/MyHEA } \\
\text { LTHKKM }\end{array}$ & $\begin{array}{l}\text { Diseases, origin of } \\
\text { sickness, treatment, } \\
\text { symptoms }\end{array}$ & Government & Youtube \\
\hline Mediktv & $\begin{array}{c}638 \\
\text { videos }\end{array}$ & $\begin{array}{l}\text { https://www.yout } \\
\text { ube.com/user/Me } \\
\text { dikTV }\end{array}$ & $\begin{array}{l}\text { Diseases, origin of } \\
\text { sickness, treatment, } \\
\text { symptoms }\end{array}$ & Ngo & Youtube \\
\hline $\begin{array}{l}\text { Dr } \\
\text { Zubaidi } \\
\text { Ahmad }\end{array}$ & 218,774 & $\begin{array}{l}\frac{\text { https://www.face }}{\text { book.com/DrZub }} \\
\text { aidiHjAhmad }\end{array}$ & $\begin{array}{l}\text { Diseases, origin of } \\
\text { sickness, treatment, } \\
\text { symptoms }\end{array}$ & $\begin{array}{c}\text { Individual / } \\
\text { physician }\end{array}$ & Facebook \\
\hline $\begin{array}{l}\text { Kevin } \\
\text { Zahri }\end{array}$ & 466,129 & $\begin{array}{l}\text { https://www.face } \\
\text { book.com/zahri.k } \\
\text { evin/?fref=ts }\end{array}$ & Health management & $\begin{array}{l}\text { Individual / } \\
\text { health } \\
\text { lifestyle }\end{array}$ & Facebook \\
\hline
\end{tabular}




\begin{tabular}{|l|l|l|l|l|l|}
\hline & & & promoter & \\
\hline $\begin{array}{l}\text { Persatua } \\
\text { n Autism } \\
\text { Malaysia }\end{array}$ & 22,337 & $\begin{array}{l}\frac{\text { https://www.face }}{\text { book.com/groups }} \\
\frac{\text { lautisme.malaysia }}{\text { l?fref=ts }}\end{array}$ & Autism & $\begin{array}{c}\text { Support } \\
\text { group }\end{array}$ & Facebook \\
\hline
\end{tabular}

In Malaysia, various organisations and government agencies has capitalised in propagating health related campaign and research indicated that social media bandwagon such as Facebook, Youtube, Instagram and Twitter are among the top choices as it resonates the public preferences when seeking information. $\mathrm{MoH}$ is the official government body to provide latest information of health to the public while for NGOs; Mercy and Makna have been the most popular site that the public referred to for information related to health. Apart from that, individuals too have gained momentum in assisting the government to spread awareness on health issue. Public figures such as Prof. Dr. Muhaya, Dr. Sahit Arshat and Kevin Zahri have been able to attract more than 100,000 followers and this show how the information on health flow from on source to many that it creates a ripple effect due to its speed, reachability and minimal cost to attain information. (Truthfully) an inexpensive media campaign using social media reaches a relatively large volume of potential consumers, at any time of day, and has a higher ROI than with traditional media. So it created higher value added to organisations [12].

The overarching focus on public health campaigns has been to utilize theoretical frameworks to plan, design, implement, and evaluate communication-based programmes that are aimed at initiating and sustaining changes in knowledge, beliefs, attitudes, and behaviours of target audience members with respect to positive health behaviours [8, 15]. Even more so in the technological advancement where the NGOs are expected to be IT savvy and possess the skills to engage online. Campaigns must be aimed at a particular, target audience for maximal impact $[8,11]$. The social media has been recognised as the most suitable outlet for the NGOs to reach out to youths in Malaysia and evidently this demographic group populates the cyberspace compare to others.

\section{Discussions}

Research on social media has grown significantly in the last decades and contributed to understanding the nature of social media and how it works. It has also paved the way for behavioural studies of its users. The usage of social media and the Internet to promote ideas and products too are becoming relevant with the advent of technologies. As technologies become cheaper and readily available, the accessibility of information through social media too thrives exponentially. As it becomes more personal to individuals, social media provide social supports to those in need. People of all demographics are adopting these technologies whether on their computers or through mobile devices, and they are increasingly using these social media for health-related issues [7]. More often than not, it serves as the silent partner to those in need. It is in this nature that the NGOs partake in communicating to the youths. The role that the NGOs play in health related campaigns assist the government to better educate the people and social media is one of the platform suitable when approaching youths.

Social network sites (SNS) are permanently changing the ways in which we interact and make sense of ourselves. This is where social media is seen as an effective tool to reach the intended public; the youths. As youth are some of the most avid users of social media, the development and availability of tailored content for this age group provides an opportunity 
to extend health promotion efforts [2]. Current technological development in Malaysia allows its citizen to enjoy hassle free internet connectivity and this is where the social media flourish especially among youths.

Given this goal and the conditions of the health market, there is a need to create unique positioning for the campaigns in order to generate public awareness [1]. Service organisations, managers, researchers and public policy makers are interested in Generation Y's use of social media because it affects people's behaviour in many domain - with positives and negative outcomes for customers, firms and their employees, and society [11]. Taking into account the influences of social media towards youths are different in each country, further study into how Malaysian youths use social media could help to determine the most suitable health campaigns that would attract in tandem with their nature, behaviour and upbringing [12]. Evidently, this clearly signals that a collective effort is much needed within and among the government, private sector and the NGOs. Whilst the government could provide up to date information and related legislations, the private sector could contribute financially and the NGOs through its widespread influence could solidify these messages through social media bandwagon.

There is a visible trend in public health literature, which emphasizes the need to effectively market public health by exploring alternative, innovative strategies [1]. The importance to carefully organize and execute a public health campaign is paramount as it involves cost and causal effects [14]. The governing bodies such as government, private sectors and NGOs are responsible to ensure the message transmit through the campaign reach and influence its target audience. In addition, public health campaign involves a systematic communicative process that aims to persuade a relatively large collection of individuals to adopt certain prescribed health messages and/or behaviours. Similarly, the NGOs championing the health related campaign must ensure that the publics are able to differentiate it so that the campaign will allow them to initiate behavioural changes in their lifestyle while at the same time initiates understanding the importance of health.

\section{References}

1. A. Basu \& J. Wang "The Role of Branding in Public Health Campaigns". Journal of Communication Management, Vol. 13 Issue 1, 1995, ISSN 1363-254X

2. B. L. Joan, et al. "A Social Media Approach to Inform Youth About Breast Cancer and Smoking: An Exploratory Descriptive Study". Collegian 21.2. pp. 159-168. (2014)

3. S. Bennett, K. Maton, \& L. Kervin, L. British Journal of Educational Technology, Vol. 39 No. 5, pp. 775-786. (2008)

4. C. Luth, G. Ranzini, \& M. Meckel "Stress 2.0: social media overload among Swiss teenagers". Communication and Information Technologies Annual Doing and Being Digital: Mediated Childhood Studies in Media and Communications, 8 pp. 3-24. (2014)

5. D'Silva, J.L., H.A.M. Shaffril, J. Uli \& B.A. Samah. Am. J. Applied, Sci., 7. (2010)

6. D. Dzuhailmi, A. Haslinda, H. Azimi, A.I Ismi, T. Ezha, A. Abdul-Lateef, S.G. Sarjit, A. Nobaya \& S. Turiman. American Journal of Applied Sciences 9 (7): 974-978, 2012, ISSN 1546-9239

7. J. Palfrey \& U. Gasser. New York, NY: Basic Books. (2008)

8. K. Holly \& I. Zena "Harnessing Social Media For Health Promotion And Behavior Change". Health Promotion Practice, 14.1. pp. 15-23. (2013)

9. K.N. Kline \& M. Mattson. Health Communication, 12, pp. 1-21. (2000)

10. L.B. Snyder "Health communication campaigns and their impact on behaviour" Journal of Nutrition Education and Behaviour, 39, pp. S32-40. (2007)

11. M.S. Wesner, and T. Miller. Organizational Development, 26 No. 3, pp. 89-96. (2008) 
12. N.B. Ruth, A. Parasuraman, A. Hoefnagels, N. Migchels, S. Kadabayi, T. Gruber, Y.K. Loureiro, \& D. Sornet. Journal of Service Management, 24 No. 3, pp. 245-267. (2013)

13. P. Farwina, J. N. Ismawati \& S. Ainin. Journal of Telematics \& Informatics, Elsevier, 32, Iss 1, pp. 67-78. (2014)

14. S. Julinawati, D. Cawley, M. Brenner, \& N.J. Rowan "Exploring health marketing strategies by the Ministry of Health Malaysia in preventing cervical cancer: A preliminary review". The 2nd International Malaysia-Ireland Joint Symposium on Engineering, Science and Business (2012)

15. S.M. Noar "A 10 year retrospective of research in health mass media campaigns: where do we go from here?". Journal of Health Communication, 11, pp. 21-42. (2006)

16. W.J. Paisley. In Rice, R.E. and Atkins, C.K. (Eds), Public Communication Campaigns, $3^{\text {rd }}$ ed., Sage, Thousand Oaks: CA, pp. 3-21. (2001) 